\title{
Factors Affecting the Promotion of Conservation Tillage in Black Soil-The Case of Northeast China
}

\author{
Yan Qu, Chulin Pan (D) and Hongpeng Guo *(D) \\ College of Biological and Agricultural Engineering, Jilin University, 5988 Renmin Street, \\ Changchun 130022, China; quyan1995@126.com (Y.Q.); pancl@jlu.edu.cn (C.P.) \\ * Correspondence: ghp@jlu.edu.cn
}

\begin{abstract}
Taking the conservation tillage influences of black soil in Northeast China as the research object, the paper is written according to the advice of relevant experts and technicians in Northeast China, the study also calculates the weight of each influencing factor through the Delphi and Analytic Hierarchy Process (AHP) method. Then, the significance of the factors affecting the benefit of conservation tillage is analyzed. The results show that, based on the comprehensive analysis, it is concluded that the economic factor is the primary factor affecting the benefit of black soil conservation tillage in Northeast China. Among the twelve influencing factors, eight of them have a significant impact on the development of conservation tillage benefits on black soil in Northeast China. Such as the degree of government subsidy; the adaptability of agricultural machinery; the input of new technology; relevant policies, laws and regulations; the quality of conservation tillage; the income of agricultural machinery farmers; practical application capacity; government publicity. Therefore, in the process of implementing the black soil conservation tillage, we should focus on these influencing factors, which will effectively promote the sustainable development of agriculture in Northeast China.
\end{abstract}

Citation: Qu, Y.; Pan, C.; Guo, H. Factors Affecting the Promotion of Conservation Tillage in Black Soil-The Case of Northeast China. Sustainability 2021, 13, 9563. https://doi.org/10.3390/su13179563

Academic Editors: Bhim Bahadur Ghaley and Andrea Pisanelli

Received: 23 July 2021

Accepted: 23 August 2021

Published: 25 August 2021

Publisher's Note: MDPI stays neutral with regard to jurisdictional claims in published maps and institutional affiliations.

Copyright: (c) 2021 by the authors. Licensee MDPI, Basel, Switzerland. This article is an open access article distributed under the terms and conditions of the Creative Commons Attribution (CC BY) license (https:/ / creativecommons.org/licenses/by/ $4.0 /)$.
Keywords: Northeast China; black soil conservation tillage; Analytic Hierarchy Process; influencing factors

\section{Introduction}

The Food and Agriculture Organization (FAO) of the United Nations' Global Soil Partnership proposed that black soils are characterized by a thick, dark-colored soil horizon, rich in organic matter. Phaeozems cover an estimated 190 million hectares worldwide. [1] The "Northeast Black Soil White Paper (2020)" issued by the Chinese Academy of Sciences shows that the total area of the black soil accounts for less than $7 \%$ of the global land area, and it is mainly concentrated in the four major black soil areas: the middle and high latitudes of central and southern North America, Russia-Ukraine Great Plains, Northeast China and Pampas in South America. The area of black soil in Northeast China ranks third. According to the data provided by the Office of the Leading Group for the Preparation of National Water and Soil Conservation Planning, the black soil area in Northeast China is located between $115^{\circ} \sim 135^{\circ} \mathrm{E}$ and $40^{\circ} \sim 50^{\circ} \mathrm{N}$, facing Russia across the Heilongiiang River and the Ussuri River to the east. The Men River and the Yalu River are adjacent to North Korea, bordering Mongolia to the west, to the Qilaotu Mountain-Hunshandake Sandy Land in the southwest, along the Inner Mongolia Plateau and to the Liaohe River in the south. The total area is 1.09 million square kilometers, accounting for about $12 \%$ of the total area of the global black soil area. It is mainly distributed in the Hulunbuir grassland, the Daxinganling region, the Sanjiang Plain, the Songnen Plain, parts of the Songliao Plain and the Changbai Mountain region, involving Heilongjiang Province and all of Jilin Province, the northeast of Liaoning Province and the "East Four Leagues" of Inner Mongolia Autonomous Region, a total of 246 counties (cities, banners). The black soil in the northeast mainly includes six soil types: black soil, chernozem soil, dark brown soil, brown soil, albic soil and meadow soil. Among them, dark brown soil has the largest 
distribution area, followed by meadow soil, followed by chernozem, black soil and albic soil, and brown soil has the smallest distribution area.

The black soil region in Northeastern China is one of the most important grain production areas in the country, and plays a key role in food security [2]. Northeast China is the main commodity grain base. According to the calculation of China's National Bureau of Statistics, the output of commercial grain in the three provinces of Northeast China will be about 138 million tons in 2020. According to the 2019 data of the China Soil and Water Conservation Bulletin, the soil erosion area of black soil in the northeast is 218,700 square kilometers, accounting for $20.11 \%$ of the total black soil area. Soil erosion mainly comes from $3^{\circ} \sim 15^{\circ}$ slope farmland, accounting for $46.39 \%$ of the total area of black soil erosion; more than $60 \%$ of the dry farmland has water and soil erosion problems, and the black soil layer is increasing at an average annual rate of $0.1 \sim 0.5 \mathrm{~cm}$ erosion loss. In recent years, black soil has decreased and degenerated heavily due to complicated functions of natural and artificial factors [3]. Overexploitation and unsustainable management measures, the soil organic matter in this area is declining and the quality of cultivated land is declining rapidly [4]. This has led to long-term exposure of black soil, degradation of soil structure and aggravation of wind erosion and water erosion in some parts of Northeast China, which poses a severe challenge to the sustainable development of agriculture and the guarantee of food security in Northeast China. On the basis of absorbing advanced foreign experience, the development of conservation tillage provides new ideas and methods to solve problems.

FAO defines conservation agriculture is an agricultural system that promotes minimal soil disturbance (i.e., no-tillage), maintains permanent soil cover and diversifies plant species. It enhances biodiversity and natural biological processes above and below the surface, helps improve water and nutrient use efficiency, and improves and maintains crop production [5]. The United States is the first country to study conservation tillage. It originated from the "black storm" event that shocked the world in the 1930s. After decades of development, it has gradually established a conservation center with straw, stubble mulch and no-tillage seeding as the core. This type of farming was developed into the mainstream farming system in the United States [6]. Conservation tillage is a commonly adopted best management practice for improving soil quality and reducing erosion [7]. In 2020, the Ministry of Agriculture and Rural Affairs and the Ministry of Finance issued the Northeast Black Soil Conservation Tillage Action Plan (2020-2025) to formulate an action plan at the national level to raise the implementation of conservation tillage in Northeast China to national action. Strengthening policy guidance and changing the traditional farming system is necessary and feasible to curb the degradation of black soil, restore and enhance the fertility of cultivated land, and consolidate the foundation of national food security [8].

Conservation tillage has become the most widely used and effective dry farming technology in the world and has attracted more attention from countries all over the world. Conservation farming is considered to be one of the most indispensable management practices for crop productivity and soil health in rainfed areas around the world. In Pothwar and other subtropical dryland areas, a reduced tillage system should be promoted to improve soil fertility and crop productivity [9]. Conservation tillage practices in the Ohio River Basin caused the ratio of crop productivity to evapotranspiration of corn and soybean increased [10]. The conservation tillage system has been demonstrated in Northeast, Northwest and South China, and semi-arid areas of the Loess Plateau of China to increase crop yield [11-18]. Studies have shown that conservation tillage may be a better farming method, which can provide a better habitat for microbial activities and soil organic carbon sequestration in Northeast China [19]. Chen and Fonteyne claimed that the density and biomass of weeds in conservation tillage were generally lower than those in conventional tillage $[20,21]$. Some experts have shown that conservation tillage (including no-tillage and reduced tillage) has a significant effect on soil properties and processes compared with conventional tillage. Long-term no-tillage and stubble retaining measures can promote 
the metabolic function of soil microbial community and form a soil bacterial community structure by changing the soil's physical and chemical properties [22-28]. Some scholars believe that conservation tillage can maintain and increase grain yield by improving soil fertility and maintaining more soil moisture in the field [29-31]. Scholars point out that decades of research on conservation tillage have produced convincing evidence that the practice of conservation tillage can be ecologically and economically beneficial to crop production and can greatly increase productivity. Despite some setbacks, on the whole, conservation tillage practice has proved to be the most beneficial [32-38]. Compared with traditional farming, conservation tillage maintains the specific structure of soil organic matter, increases microbial biomass, increases the concentration of soil organic carbon, changes the composition of soil organic matter and reduces the degradation of soil organic matter [39]. Sadiq, M. concluded that conservation tillage practices could replace conventionally tilled practice with respect to productivity, soil mineral nitrogen and carbon accumulation benefits [40].

Through literature review, as an important system engineering, conservation tillage needs to consider the interaction of internal and external factors. According to current scholars' research, cultivated land policies and measures vary from country to country, and on the whole, attention is still focused on the soil properties of cultivated land and cultivated land protection policies. China, as a large agricultural country, needs to learn more from foreign advanced farmland protection technologies and research methods when promoting conservation tillage. According to the status of regional cultivated land use, a reasonable and scientific index system should be established to comprehensively analyze the new pattern of implementation of conservation tillage, so as to lay a reference foundation for the effective utilization of black soil resources in the future. Black soil protection is an important measure for green and sustainable development in agriculture. Conservation tillage is a revolutionary farming measure that synchronizes ecological and economic benefits, takes into account both current and long-term interests, and benefits the country and the people. In order to make the black soil sustainable use, we must adhere to the combination of use and maintenance, protection and utilization. We will co-ordinate the relationship among increasing grain production, increasing farmers' income and protect black soil, adjust and optimize planting structure and production capacity, and promote resource-saving and environment-friendly technologies. Therefore, this paper uses the Delphi and Analytic Hierarchy Process method to comprehensively consider the factors affecting the promotion of black soil conservation farming in Northeast China. This study provides data support and empirical evidence for the next step to better promote the black soil conservation tillage technology in China.

\section{Data and Methods}

\subsection{Data}

According to the investigation of the application of conservation tillage technology in Northeast China, Daxing'anling region, Qitaihe City, Heihe City, Yichun City, Suihua City and Shuangyashan City in Heilongjiang Province were selected. Among them, Jilin Province selected the following regions including Changchun City, Siping City, Jilin City, Liaoyuan City, Dongfeng County, and Nong'an County. Due to the small area of black soil in Liaoning Province, it is mainly concentrated in Changtu, which is the main research area. A total of 32 people visited conservation tillage experts, co-operatives and related technical personnel. The main methods include face-to-face access, telephone access, network communication, etc. By filling in the questionnaire and modifying and developing the evaluation index items one by one, the final design of the questionnaire is completed.

Some experts use the Delphi method and the Analytic Hierarchy Process method to evaluate the ecosystem, establish relevant judgment matrices and calculate the weights of each indicator layer and variable layer, respectively. The fuzzy comprehensive evaluation method is used to evaluate the sustainability of the conservation tillage system [41-43]. Referring to the literature review and some research conclusions and considering the inves- 
tigation of black soil conservation tillage in Northeast China, we had revised and developed the title of the evaluation index, and finally completed the design of the questionnaire.

In this study, the influencing factors of black soil conservation tillage benefits in Northeast China can be summarized as follows: policy factors, economic factors, farmers level and technical level. See Table 1 for details.

Table 1. The Factor System Construction.

\begin{tabular}{|c|c|c|}
\hline Target & Main Factor & Subfactor \\
\hline \multirow{4}{*}{$\begin{array}{l}\text { The influencing factors of black soil } \\
\text { conservation tillage benefits in } \\
\text { Northeast China A }\end{array}$} & Policy factors A1 & $\begin{array}{c}\text { Relevant policies, laws and regulations B1 } \\
\text { Government publicity B2 } \\
\text { Government management B3 }\end{array}$ \\
\hline & Economic factors A2 & $\begin{array}{c}\text { The degree of government subsidy B4 } \\
\text { The income of agricultural machinery farmers B5 } \\
\text { The input of new technology B6 }\end{array}$ \\
\hline & Farmer level A3 & $\begin{array}{l}\text { Acceptability of technology B7 } \\
\text { Participation in technical training B8 } \\
\text { Practical application capacity B9 }\end{array}$ \\
\hline & Technical level A4 & $\begin{array}{c}\text { The adaptability of agricultural machinery B10 } \\
\text { The quality of conservation tillage B11 } \\
\text { Conservation tillage mode B12 }\end{array}$ \\
\hline
\end{tabular}

Therefore, the questionnaire design of the influencing factors of black soil conservation tillage in Northeast China will also be carried out from these four aspects, and the specific evaluation indexes included in each aspect are as follows:

(1) Policy factors: mainly including the relevant policy factors, government publicity and the government's management.

(2) Economic factors: mainly including the degree of government subsidy, farmers' income and the input of new technology.

(3) Farmers' level: mainly including the ability to accept technology, participation in technical training, implementation and practical application capacity.

(4) Technical level: mainly including the adaptability of agricultural machinery, the quality of conservation tillage and conservation tillage mode.

\subsection{Methods}

Analytic Hierarchy Process (AHP) is a practical multi-scheme or multi-objective decision-making method proposed by American operations researcher Professor T.L. Saaty in the 1970s. It is often used in unstructured and complex decision-making problems with multiple goals, multiple criteria, multiple elements and multiple levels, especially strategic decision-making problems. It has a wide range of practicality [44].

\subsubsection{Construct Judgment Matrix}

Hierarchy reflects the relationship between factors, but the proportion of each criterion in the target measurement is not necessarily the same in different decision-makers' minds. When it comes to some problems, some elements may have different ideas for everyone, so it is not easy to obtain accurate evaluation results for such elements, which may even be contradictory. See Table 2 for details [45]. 
Table 2. AHP Assessment Scale and Explanation.

\begin{tabular}{|c|c|c|}
\hline Evaluation Scale & Definition & Explanation \\
\hline 1 & Equal importance & The two being compared are equally important \\
\hline 3 & Weak importance & $\begin{array}{l}\text { Experience and judgment are slightly inclined to } \\
\text { one side }\end{array}$ \\
\hline 5 & Essential importance & $\begin{array}{c}\text { Experience and judgment are strongly inclined } \\
\text { towards one side }\end{array}$ \\
\hline 7 & Very strong importance & $\begin{array}{c}\text { The actual situation shows a very strong } \\
\text { preference for one side }\end{array}$ \\
\hline 9 & Absolute importance & $\begin{array}{l}\text { There is sufficient evidence to support a certain } \\
\text { absolute preference }\end{array}$ \\
\hline $2,4,6,8$ & Intermediate values & When a compromise is needed \\
\hline
\end{tabular}

Research shows that when there are too many factors in pairwise comparison, people's judgment will be greatly affected, generally speaking, it is more appropriate to be in the range of $7 \pm 2$. If it is limited to 9 , it is appropriate to use the scale of $1-9$ to indicate the difference between them. Moreover, in comparison, it is necessary to make $n(n-1) / 2$ pairwise judgment, which can provide more information, and can also obtain a more reasonable ranking through repeated comparison in various aspects.

\subsubsection{Hierarchical Order and Consistency Check}

Hierarchical ordering refers to calculating the weights of the order of importance of factors in the previous level for a factor in the previous level based on the obtained judgment matrix. This process is called hierarchical ordering. The main purpose of this process is to calculate the eigenvalue and eigenvector of each judgment matrix, by using the formula $A W=\lambda_{\max } W$. A is the judgment matrix, $\lambda_{\max }$ is the maximum eigenvalue of the judgment matrix, $W$ is the corresponding eigenvector, and each element of the eigenvector of $W$ is the weight value of the required level order.

The eigenvector $W$ and the maximum eigenvalue $\lambda_{\max }$ of the judgment matrix can be calculated by using the sum method, root method and power method. Here, the sum method is employed for calculation. The calculation steps are as follows:

(1) Firstly, each column of the judgment matrix is normalized.

$$
b_{i j}=\frac{\mathrm{a}_{i j}}{\sum_{i=1}^{n} a_{i j}}(i, j=1,2,3, \ldots, n)
$$

After normalization, the sum of the elements in each column is 1.

(2) The normalized judgment matrix of each column is added by row.

$$
V_{i}=\sum_{j=1}^{n} b_{i j}(i, j=1,2,3, \ldots, n)
$$

(3) Then normalize the vector $V=\left[V_{1}, V_{2}, \ldots, V_{n}\right]^{T}$.

$$
\mathrm{w}_{i}=\frac{v_{i}}{\sum_{i=1}^{n} v_{i}}(i=1,2,3, \ldots, n)
$$

The resulting vector $\left[w_{1}, w_{2}, \ldots, w_{n}\right]^{T}$ is the weight vector.

(4) Finally, calculate the largest characteristic root $\lambda_{\max }$ of the judgment matrix.

$$
\lambda_{\max }=\sum_{i=1}^{\mathrm{n}} \frac{(A W)_{i}}{n W_{i}}(i, j=1,2,3, \ldots, n)
$$


In the above formula, $(A W)_{i}$ is the $i$ th element of $A W$, and $N$ is the order. Because the experts compare the factors by pairs, there may be a self-contradictory phenomenon. Therefore, in order to avoid this phenomenon, the consistency must be tested. The steps of inspection are as follows:

(5) Calculate the consistency index CI:

$$
C I=\frac{\lambda_{\max }-n}{n-1},(n \text { is the order of the judgment matrix })
$$

The consistency index $C I$ is a measure of the degree of deviation of the judgment matrix A from the original matrix composed of its main feature vector.

(6) Define the mean value $R I$ of random consistency index:

For $n=3-9$ orders, after calculation, RI can be obtained separately. Considering that the judgment matrix of order 1, 2 is always completely consistent, the value of $R I$ is naturally 0 . Therefore, the RI of the judgment matrix of order 1-9 is shown in Table 3:

Table 3. Random Index Table.

\begin{tabular}{cccccccccc}
\hline $\mathbf{N}$ & $\mathbf{1}$ & $\mathbf{2}$ & $\mathbf{3}$ & $\mathbf{4}$ & $\mathbf{5}$ & $\mathbf{6}$ & $\mathbf{7}$ & $\mathbf{8}$ & $\mathbf{9}$ \\
\hline$R I$ & 0.00 & 0.00 & 0.58 & 0.90 & 1.12 & 1.24 & 1.32 & 1.41 & 1.45 \\
\hline
\end{tabular}

In the table, when $n=1,2, R I=0$, because the reciprocal matrix of order 1,2 is always consistent.

(7) Calculate the consistency ratio $C R$ :

$$
C R=\frac{C I}{R I}
$$

For the judgment matrix A with $n>3$, compare the calculated $C I$ with the RI of the same order (meaning that $\mathrm{n}$ is the same), and the ratio of the two is $C R$. When the ratio is less than or equal to 0.1 (i.e., $C R<0.10$ ), it is considered that the degree of inconsistency of $\mathrm{A}$ is within an allowable range, which means that the test is passed. When the ratio is greater than 0.1 , the judgment matrix does not pass the consistency test, and the judgment matrix needs to be appropriately modified and continue to be tested until it passes.

According to the indicator system, using the above-mentioned scaling method, and through the questionnaire survey of the expert consultation method, 32 experts in this field in Northeast China were selected to score the significance of the indicators, with internal discussions and generalizations conducted on the scoring results. The pairwise discrimination matrix is shown in Table 4:

Table 4. Judgment Matrix A-Ai (i=1, 2, 3, 4).

\begin{tabular}{ccccc}
\hline Influencing Factors A & Policy Factors A1 & Economic Factors A2 & Farmer Level A3 & Technical Level A4 \\
\hline Policy factors A1 & 1 & $1 / 3$ & 2 & $1 / 2$ \\
Economic factors A2 & 3 & 1 & 4 & 2 \\
Farmer level A3 & $1 / 2$ & $1 / 4$ & 1 & $1 / 3$ \\
Technical level A4 & 2 & $1 / 2$ & 3 & 1 \\
\hline
\end{tabular}

The maximum eigenvalue of the judgment matrix is calculated $\lambda_{\max }=4.0310$. Then the consistency test is carried out, and the consistency index $C I$ is calculated.

$$
C I=\frac{\lambda_{\max }-n}{n-1}=\frac{4.0310-4}{4-1}=0.0103
$$


Average random consistency index $R I=0.9$. Random consensus ratio:

$$
C R=\frac{C I}{R I}=\frac{0.0103}{0.9}=0.0115<0.10
$$

Since $C R$ is less than 0.1 , it can be concluded that the construction of the judgment matrix is reasonable. The weight of each index is calculated by the method of Analytic Hierarchy Process. To construct the judgment matrix $S=\left(u_{i j}\right)_{p \times p^{\prime}}$ see Table 5 .

Table 5. Judgment Matrix A1-Bi $(i=1,2,3)$.

\begin{tabular}{cccc}
\hline Policy Factors A1 & $\begin{array}{c}\text { Relevant Policies, Laws and } \\
\text { Regulations B1 }\end{array}$ & Government Publicity B2 & Government Management B3 \\
\hline Relevant policies, laws and & 1 & 2 & 4 \\
regulations B1 & $1 / 2$ & 1 & 3 \\
Government publicity B2 & $1 / 4$ & $1 / 3$ & 1 \\
Government management B3 & & $1 / 3$ \\
\hline
\end{tabular}

The maximum eigenvalue of the judgment matrix is calculated $\lambda_{\max }=3.0183$. Then the consistency test is carried out, and the consistency index CI is calculated.

$$
C I=\frac{\lambda_{\max }-n}{n-1}=\frac{3.0183-3}{3-1}=0.0091
$$

Average random consistency index $R I=0.58$. Random consensus ratio:

$$
C R=\frac{C I}{R I}=\frac{0.0091}{0.58}=0.0158<0.10
$$

As $C R$ is less than 0.1 , it can be concluded that the construction of judgment matrix is reasonable. The weight of each index is calculated by the method of Analytic Hierarchy Process. To construct the judgment matrix $S=\left(u_{i j}\right)_{p \times p^{\prime}}$ see Table 6 .

Table 6. Judgment Matrix A2-Bi $(i=4,5,6)$.

\begin{tabular}{ccc}
\hline Economic Factors A2 & $\begin{array}{c}\text { The Degree of } \\
\text { Government Subsidy B4 }\end{array}$ & $\begin{array}{c}\text { The Income of Agricultural } \\
\text { Machinery Farmers B5 }\end{array}$ \\
\hline $\begin{array}{c}\text { The degree of government subsidy B4 } \\
\text { The income of agricultural machinery farmers B5 }\end{array}$ & 1 & 3 \\
The input of new technology B6 & $1 / 3$ & 1 \\
Technology B6
\end{tabular}

The maximum eigenvalue of the judgment matrix is calculated $\lambda_{\max }=3.0092$. With the consistency test conducted, the consistency index CI is calculated.

$$
C I=\frac{\lambda_{\max }-n}{n-1}=\frac{3.0092-3}{3-1}=0.0046
$$

Average random consistency index $R I=0.58$. Random consensus ratio:

$$
C R=\frac{C I}{R I}=\frac{0.0046}{0.58}=0.0079<0.10
$$

Owning to $C R$ being less than 0.1 , it can be concluded that the construction of the judgment matrix is rational. The weight of each index is calculated by the method of Analytic Hierarchy Process, in order to construct the judgment matrix $S=\left(u_{i j}\right)_{p \times p^{\prime}}$, see Table 7. 
Table 7. Judgment Matrix A3-Bi $(i=7,8,9)$.

\begin{tabular}{cccc}
\hline Farmer Leve A3 & $\begin{array}{c}\text { Acceptability of } \\
\text { Technology B7 }\end{array}$ & $\begin{array}{c}\text { Participation in Technical } \\
\text { Training B8 }\end{array}$ & $\begin{array}{c}\text { Practical Application } \\
\text { Capacity B9 }\end{array}$ \\
\hline Acceptability of technology B7 & 1 & 2 & $1 / 3$ \\
Participation in technical training B8 & $1 / 2$ & 1 & $1 / 5$ \\
Practical application capacity B9 & 3 & 5 & 1 \\
\hline
\end{tabular}

The maximum eigenvalue of the judgment matrix is calculated $\lambda_{\max }=3.0037$. With the consistency test completed, the consistency index CI is calculated.

$$
C I=\frac{\lambda_{\max }-n}{n-1}=\frac{3.0037-3}{3-1}=0.0018
$$

Average random consistency index $R I=0.58$. Random consensus ratio:

$$
C R=\frac{C I}{R I}=\frac{0.0018}{0.58}=0.0032<0.10
$$

Due to $C R$ being less than 0.1 , it can be concluded that the construction of the judgment matrix is reasonable. The weight of each index is calculated by the method of Analytic Hierarchy Process, so as to construct the judgment matrix $S=\left(u_{i j}\right)_{p \times p^{\prime}}$, see Table 8 .

Table 8. Judgment Matrix A4-Bi (i=10, 11, 12).

\begin{tabular}{ccc}
\hline Technical Level A4 & $\begin{array}{c}\text { The Adaptability of } \\
\text { Agricultural Machinery B10 }\end{array}$ & $\begin{array}{c}\text { The Quality of Conservation } \\
\text { Tillage B11 }\end{array}$ \\
\hline The adaptability of agricultural machinery B10 & 1 & 2 \\
The quality of conservation tillage B11 & $1 / 2$ & 1 \\
Conservation tillage mode B12 & $1 / 5$ & $1 / 2$ \\
\hline
\end{tabular}

The maximum eigenvalue of the judgment matrix is calculated $\lambda_{\max }=3.0055$. With the consistency test performed, the consistency index $C I$ is calculated.

$$
C I=\frac{\lambda_{\max }-n}{n-1}=\frac{3.0055-3}{3-1}=0.0028
$$

Average random consistency index $R I=0.58$. Random consensus ratio:

Since $C R$ is less than 0.1 , it can be concluded that the construction of the judgment matrix is reasonable. Finally, the weight distribution and ranking of the index layer are

\begin{tabular}{|c|c|c|c|c|c|}
\hline Main factors & Weights & Subfactors & Weights & Comprehensive Weights & Sequence \\
\hline \multirow{3}{*}{$\begin{array}{l}\text { Policy factors } \\
\text { A1 }\end{array}$} & \multirow{3}{*}{0.1601} & Relevant policies, laws and regulations B1 & 0.5584 & 0.0894 & 4 \\
\hline & & Government publicity B2 & 0.3196 & 0.0512 & 8 \\
\hline & & Government management B3 & 0.1220 & 0.0195 & 11 \\
\hline \multirow{3}{*}{$\begin{array}{c}\text { Economic } \\
\text { factors } \\
\text { A2 }\end{array}$} & \multirow{3}{*}{0.4673} & The degree of government subsidy B4 & 0.5396 & 0.2522 & 1 \\
\hline & & The income of agricultural machinery farmers B5 & 0.1634 & 0.0764 & 6 \\
\hline & & The input of new technology B6 & 0.2970 & 0.1388 & 3 \\
\hline \multirow{3}{*}{$\begin{array}{c}\text { Farmer level } \\
\text { A3 }\end{array}$} & \multirow{3}{*}{0.0954} & Acceptability of technology B7 & 0.2297 & 0.0219 & 10 \\
\hline & & Participation in technical training B8 & 0.1220 & 0.0116 & 12 \\
\hline & & Practical application capacity B9 & 0.6483 & 0.0618 & 7 \\
\hline \multirow{3}{*}{$\begin{array}{c}\text { Technical } \\
\text { level } \\
\text { A4 }\end{array}$} & \multirow{3}{*}{0.2772} & The adaptability of agricultural machinery B10 & 0.5954 & 0.1650 & 2 \\
\hline & & The quality of conservation tillage B11 & 0.2764 & 0.0766 & 5 \\
\hline & & Conservation tillage mode B12 & 0.1283 & 0.0356 & 9 \\
\hline
\end{tabular}
shown in Table 9.

Table 9. Weights of Main Factors and Subfactors. 


\section{Results}

As shown in Table 9, the 12 independent variables have different degrees of effects on the dependent variables. The weight results of influencing factors of conservation tillage benefits in Northeast China are explained separately as follows.

Among the twelve factors, eight factors have a strong impact on the development of conservation tillage efficiency of black soil in Northeast China. The results show that the weight of government subsidy degree is 0.2522 , the weight of agricultural machinery adaptability is 0.1650 , the weight of new technology input is 0.1388 , the weight of relevant policies and laws and regulations is 0.0894 , the weight of conservation tillage quality is 0.0766, the weight of agricultural machinery farmers income is 0.0764 and the weight of practical application capacity is 0.0618 , The weight value of government publicity is 0.0512 , and the weight value of the remaining four factors does not mean that its influencing factors are not important.

(1) The weight of government subsidy degree is 0.2522 . The degree of government subsidy is the most important factor in economic factors. The application of conservation tillage technology needs a lot of capital investment, including the cost of supporting agricultural machinery, fertilizer and herbicide, and the training of technical personnel. It is necessary for the state and government departments to increase financial support, strengthen financial subsidies for machine purchase subsidies, personnel training, technology promotion and other aspects, and complete the effective promotion of conservation tillage technology in the northeast black soil area.

(2) The weight agricultural machinery adaptability is 0.1650 . The adaptability of agricultural machinery is the key factor at the technical level. The implementation of conservation tillage requires the adaptability of agricultural machinery to crops, plots and cultivation systems. At the same time, it requires agricultural machinery users to understand the performance of agricultural machinery, select appropriate agricultural machinery products and guide farmers to use appropriate conservation tillage machines.

(3) The weight of new technology input is 0.1388 . Conservation tillage is not only the transformation of agricultural technology, but also the effective combination of agricultural machinery and agricultural technology. Agricultural machinery and agricultural technology have experienced many changes in farming management system, farming habits, farming management mode and so on. As a new mechanism and mode, conservation tillage is a supporting strategy in line with the characteristics and laws of agricultural science and technology, which greatly improves the input level and use efficiency of agricultural science and technology.

(4) The weight of relevant policies, laws and regulations is 0.0894 . Relevant policies, laws and regulations are the most important factors in policy factors. It can guide and strengthen the implementation of conservation tillage and make conservation tillage run more orderly in the promotion.

(5) The weight value of conservation tillage quality is 0.0766 . Conservation tillage technology directly affects the yield of crops, as far as possible to ensure that there are few mistakes in any link and to ensure that the operation quality is improved under the condition of the implementation of conservation tillage, so that the technology can achieve the desired effect.

(6) The weight value of agricultural machinery farmers income is 0.0764 . In the process of conservation tillage, seeder, deep plough, subsoiler and other supporting equipment should be used. Therefore, agricultural machinery households need to master market information and financial support. At the same time, the state subsidizes farmers to purchase agricultural machinery, promotes cost saving and efficiency agricultural mechanization technology, promotes the industrialization of agricultural machinery services and promotes the development of modern agriculture.

(7) The weight of practical application capacity is 0.0618 . The application of conservation tillage needs to guide practice on the basis of theory. After the demonstration 
of conservation tillage project, farmers need to practice the technology to improve the maturity of conservation tillage technology.

(8) The weight value of government publicity is 0.0512 . The government's propaganda is also necessary for technology promotion. The government should do a good job of guidance through publicity, demonstration, subsidies and other ways. So that the local farmers' awareness of conservation tillage technology and the implementation effect has been improved, thus promoting the promotion and application of conservation tillage technology in the next large area of agricultural production.

(9) The weight of conservation tillage mode is 0.036 . The promotion of conservation tillage mode is one of the factors affecting the implementation of conservation tillage. Different crops adopt different conservation tillage modes. It is an important way to adopt the cultivation mode according to local conditions, so as to promote the sustainable development of agriculture, protect soil and improve soil use efficiency.

(10) The weight of technology acceptability is 0.022 . Conservation tillage is not only the improvement of agricultural technology, but also a series of improvements to the farming system; at present, most farmers are accustomed to the existing mode of production and pay more attention to crop yield, short-term economic benefits and risks. Therefore, to strengthen the understanding of conservation tillage, technology must continue to deepen in order to gradually be accepted by people.

(11) The weight of government management is 0.020 . Government management, that is, government behavior, has an important impact on whether farmers adopt conservation tillage technology. It includes the guiding behavior of the state, the future development direction, scientific and technological innovation, and the demonstration role.

(12) The weight of participation in technical training is 0.012 . Through participating in technical training, we can make scientific specifications for the specific implementation of conservation tillage, and drive farmers to carry out an all-round, deep-seated and multi-angle development of conservation tillage with high quality.

Among the twelve factors, the weight value of 0.05 is taken as the reference value, meaning that eight factors have a great impact on the development of conservation tillage efficiency of black soil in Northeast China. In contrast, the weight value of conservation tillage mode, technology acceptability, government management and participation in technical training is less obvious.

\section{Discussion}

The experience of agricultural development at home and abroad has fully demonstrated that conservation tillage technology is an ecological technology, and it is also a sustainable development technology. It is different from traditional farming techniques, not only in content and technology, but also in many aspects and links of traditional farming that need to be adjusted, requiring strong policy support. For example, issues such as the farming system, technology promotion and use of funds. Therefore, a sound policy has been formulated for the promotion of conservation tillage technology for relevant departments, and the relevant departments should be correctly guided to promote the work of new technologies. This paper analyzes the influencing factors of the promotion of black soil conservation tillage in Northeast China. The study found that the long-term mechanism of conservation tillage has not been established. The knowledge of extension personnel and technicians needs to be further improved, and farmers still need time to gradually accept it. Through interviews with experts and technicians, it is concluded that the promotion of conservation tillage requires government policy support and expert technical guidance on black soil conservation tillage techniques in the Northeast China.

On the one hand, it is very necessary for the government to guide farmers to accept the new technology of conservation tillage. Subsidies are an important means for government departments to encourage farmers to implement conservation tillage technology. However, black soil conservation tillage subsidies in Northeastern China are different from other traditional agricultural subsidies. For example, the basic form of the EU agricultural 
protection policy is to control the scale of agricultural production, implement a fallow system, freeze $15 \%$ of the cultivated area of cereals and treat fallow agricultural producers. According to the average output per unit area in different regions, corresponding subsidies will be given, and a limited mandatory fallow plan will be implemented, and voluntary fallow will be rewarded [46]. Conservation tillage techniques of black soil in Northeast China are not fallow. They are sustainable agricultural technologies through comprehensive supporting measures such as less tillage, no-tillage, surface micro terrain transformation technology, surface coverage and rational planting, so as to reduce farmland soil erosion, protect farmland ecological environment, and obtain co-ordinated development of ecological, economic and social benefits [47]. In recent years, significant progress has been made in conservation tillage in Northeast China. The technical model has the basis for comprehensive popularization and application in appropriate areas. Through agricultural production subsidies, it is implemented by means of government purchase of services, "operation before subsidy, publicity before cash", so as to improve the implementation efficiency and operation quality of subsidies.

According to the policy basis for the implementation of the "Northeast Black Soil Conservation Tillage Action Plan", the study found that subsidized farmers are more inclined to adopt the technology, which indicates that the government should provide guidance through propaganda, demonstration and subsidies, especially to increase the intensity and duration of subsidies At the same time, local governments should focus on promoting conservation tillage technologies in local economic development and soil planning, and establish more conservation farming demonstration areas to provide strong support for their technologies. They should also purchase suitable agricultural machinery for farmers and issue corresponding agricultural machinery subsidies, so as to increase farmers' enthusiasm to actively purchase supporting agricultural machinery, so that farmers have a correct and comprehensive understanding of new agricultural technology and can gradually accept it, which is effective for conservation tillage techniques and economic benefits. Therefore, subsidized farmers have a higher understanding and are more likely to promote the popularization and application of conservation tillage techniques.

On the other hand, in the practice of conservation tillage in black soil, there is a problem of disconnection between agricultural machinery and agronomy, which restricts the application and popularization of conservation tillage technology [48]. The results show that the implementation of conservation tillage technology requires farmers to use agricultural machines and tools correctly, and the rational use of agricultural machines and tools is the key to the implementation of conservation tillage technology. Therefore, the agricultural machinery R \& D department needs to develop agricultural machinery with a moderate price, excellent performance and suitable for conservation tillage, strengthen the quality supervision of agricultural machinery products, improve the performance of machines and tools and ensure the quality of products, so as to meet the technical requirements of production and operation in various regions.

On the whole, conservation tillage technology is not only the revolution of agricultural technology, but also the reform of agricultural systems and farm management practices. Conservation tillage is not only the main development direction of international agricultural technology, but also the means to realize sustainable agricultural technology in China. The promotion and implementation of conservation tillage technology is a systematic project, which should adhere to the promotion of long-term continuity. Therefore, the research and popularization of conservation tillage need long-term investment to further promote the comprehensive application of conservation tillage in the black soil farming area of Northeast China.

\section{Conclusions}

Based on the analysis of the factors affecting the popularization of conservation tillage in black soil of Northeast China, and the questionnaire survey of 32 experts and technicians in this field in Northeast China, the Analytic Hierarchy Process was employed to 
analyze, construct the hierarchical model, calculate the judgment matrix and the maximum eigenvalue, and sort the weight values of all factors. Of the twelve influencing factors, eight have a significant impact on the improvement in the efficiency of black soil conservation tillage in Northeast China. Experts and technicians identify such objective factors as the degree of government subsidy, adaptability of agricultural machinery, new technology investment, relevant policies and laws and regulations, and government level as the more significant factors, and the subjective factors including farmer level as relatively important ones.

According to the research conclusions of this article, the following policy impacts can be drawn. First, the conservation tillage of black soil will be raised to the national strategic level, and the government will be established and improved to maintain the continuity and stability of policy support. Second, increase financial support for the research and development, demonstration and promotion of black soil conservation tillage technology, and improve the promotion efficiency of the promotion model of conservation tillage technology. Third, strengthen the publicity, training and demonstration of farmers, and enhance farmers' awareness of black soil conservation tillage and their enthusiasm for implementing conservation tillage techniques.

Author Contributions: Conceptualization, Y.Q. and H.G.; methodology, Y.Q. and C.P.; software, Y.Q. and C.P.; validation, Y.Q and C.P.; formal analysis, Y.Q.; resources, Y.Q.; data curation, Y.Q.; writing—original draft preparation, Y.Q.; writing—review and editing, Y.Q. and H.G.; visualization, H.G.; supervision, H.G. and C.P.; project administration, H.G. and C.P.; funding acquisition, H.G. and C.P. All authors have read and agreed to the published version of the manuscript.

Funding: This research was funded by Social Science Fund Project of Jilin Province, China, grant No.2017B35; MOE (Ministry of Education in China) Project of Humanities and Social Sciences, grant/award No.18YJC630128; the Social Science Fund Project of "the 13th Five-Year" of Education Department of Jilin Province, China, grant No.JJKH20190736SK.

Institutional Review Board Statement: Not applicable.

Informed Consent Statement: Not applicable.

Data Availability Statement: Data sharing not applicable.

Conflicts of Interest: The authors declare no conflict of interest.

\section{References}

1. FAO International Network of Black Soils. Available online: http://www.fao.org/global-soil-partnership/intergovernmentaltechnical-panel-soils/gsoc17-implementation/internationalnetworkblacksoils/it/ (accessed on 8 November 2018).

2. Baoyuan, L. The scope and demarcation of northeast black soil area and northeast typical black soil area. Chin. Sci. Bull. 2021, 66, 96-106.

3. Yan, B.; Zhang, Y.; Zang, S.; Chen, Q.; Sun, L. Distributions of Particle Sizes in Black Soil and Their Environmental Significance in Northeast China. Sustainability 2021, 13, 3706. [CrossRef]

4. Du, Z.; Gao, B.; Ou, C.; Du, Z.; Yang, J.; Batsaikhan, B.; Dorjgotov, B.; Yun, W.; Zhu, D. A Quantitative Analysis of Factors Influencing Organic Matter Concentration in the Topsoil of Black Soil in Northeast China Based on Spatial Heterogeneous Patterns. ISPRS Int. J. Geo-Inf. 2021, 10, 348. [CrossRef]

5. FAO Conservation Agriculture. Available online: http://www.fao.org/conservation-agriculture/en/ (accessed on 15 August 2021).

6. Kang, H.; Iwao, H.; Nobuyuki, I. Estimation and Measurement of the Sound Power Radiated from a Circular Plate with a Solid Shaft and a Solid Cylinder. JSME Int. J. Ser. C Mech. Syst. Mach. Elem. Manuf. 1998. [CrossRef]

7. Sullivan, D.G.; Strickland, T.C.; Masters, M.H. Satellite mapping of conservation tillage adoption in the Little River experimental watershed, Georgia. J. Soil Water Conserv. 2008, 63, 112-119. [CrossRef]

8. Ministry of Agriculture and Rural Affairs of the People's Republic of China. The Ministry of Agriculture and Rural Areas and the Ministry of Finance Issued the Action Plan for Conservation Tillage on Black Soil in Northeast China (2020-2025). Available online: http:/ / www.gov.cn/xinwen/2020-03/18/content_5492780.html (accessed on 12 August 2021).

9. ur Rehman, S.; Ijaz, S.S.; Khan, K.S.; Ansar, M.; Hussain, Q. Soil nutrient status and crop productivity after 6 years of conservation tillage in a subtropical dryland. Arab. J. Geosci. 2021, 14, 180. [CrossRef]

10. Huang, Y.; Tao, B.; Zhu, X.; Yang, Y.; Ren, W. Conservation tillage increases corn and soybean water productivity across the Ohio River Basin. Agric. Water Manag. 2021, 254, 106962. [CrossRef] 
11. Wang, W.; Xu, F.; Li, X.; Li, L. The soil moisture content affected by mulching methods in Weibei rainfed highland. Acta Agric. Boreali-Occident. Sin. 2001, 10, 56-58.

12. Tan, C.; Cao, X.; Yuan, S.; Wang, W.; Feng, Y.; Qiao, B. Effects of Long-term Conservation Tillage on Soil Nutrients in Sloping Fields in Regions Characterized by Water and Wind Erosion. Sci. Rep. 2015, 5, 17592. [CrossRef] [PubMed]

13. Liu, S.; Zhang, X.; Liang, A.; Zhang, J.; Müller, C.; Cai, Z. Ridge tillage is likely better than no tillage for 14-year field experiment in black soils: Insights from a $15 \mathrm{~N}$-tracing study. Soil Tillage Res. 2018, 179, 38-46. [CrossRef]

14. Zhang, Y.; Wang, S.; Wang, H.; Ning, F.; Zhang, Y.; Dong, Z.; Wen, P.; Wang, R.; Wang, X.; Li, J. The effects of rotating conservation tillage with conventional tillage on soil properties and grain yields in winter wheat-spring maize rotations. Agric. For. Meteorol. 2018, 263, 107-117. [CrossRef]

15. Wu, X.; Tang, Y.; Li, C.; McHugh, A.D.; Liu, M.; Li, M.; Xiong, T. In Situ Maize Residue Mulch Improves the Water Use Efficiency and Yield of the Subsequent Wheat under a Strip Inter-Cropping System. Agron. J. 2019, 111, 924-934. [CrossRef]

16. Wang, S.; Guo, L.; Zhou, P.; Wang, X.; Shen, Y.; Han, H.; Ning, T.; Han, K. Effect of subsoiling depth on soil physical properties and summer maize (Zea mays L.) yield. Plant Soil Environ. 2019, 65, 131-137. [CrossRef]

17. Yin, W.; Fan, Z.; Hu, F.; Yu, A.; Zhao, C.; Chai, Q.; Coulter, J.A. Innovation in alternate mulch with straw and plastic management bolsters yield and water use efficiency in wheat-maize intercropping in arid conditions. Sci. Rep. 2019, 9, 6364. [CrossRef] [PubMed]

18. Li, T.; Li, Y.; Gao, X.; Wang, S.; Liao, Y. Rhizobacterial communities and crop development in response to long-term tillage practices in maize and soybean fields on the Loess Plateau of China. Catena 2021, 202, 105319. [CrossRef]

19. Jia, S.; Zhang, X.; Chen, X.; Mclaughlin, N.B.; Zhang, S.; Wei, S.; Sun, B.; Liang, A. Long-term conservation tillage influences the soil microbial community and its contribution to soil CO2 emissions in a Mollisol in Northeast China. J. Soils Sediments 2016, 16, 1-12. [CrossRef]

20. Chen, X.W. Earthworm Positively Influences Large Macropores under Extreme Drought Conditions and Conservation Tillage in a Chinese Mollisol. Appl. Ecol. Environ. Res. 2018, 16, 663-675. [CrossRef]

21. Fonteyne, S.; Singh, R.G.; Govaerts, B.; Verhulst, N. Rotation, Mulch and Zero Tillage Reduce Weeds in a Long-Term Conservation Agriculture Trial. Agronomy 2020, 10, 962. [CrossRef]

22. Chan, K.Y. An overview of some tillage impacts on earthworm population abundance and diversity-Implications for functioning in soils. Soil Tillage Res. 2001, 57, 179-191. [CrossRef]

23. Wright, A.L.; Hons, F.M.; Matocha, J.E. Tillage impacts on microbial biomass and soil carbon and nitrogen dynamics of corn and cotton rotations. Appl. Soil Ecol. A 2005, 29, 85-92. [CrossRef]

24. Jin, H.; Hongwen, L.; Xiaoyan, W.; Hugh, M.; Wenying, L.; Huanwen, G.; Kuhn, N.J. The adoption of annual subsoiling as conservation tillage in dryland maize and wheat cultivation in northern China. Soil Tillage Res. 2007, 94, 493-502. [CrossRef]

25. Bhan, S.; Behera, U.K. Conservation agriculture in India-Problems, prospects and policy issues. Int. Soil Water Conserv. Res. 2014, 2, 1-12. [CrossRef]

26. Figueiredo, P.G.; Bicudo, S.J.; Chen, S.; Fernandes, A.M.; Tanamati, F.Y.; Djabou-Fondjo, A.S.M. Effects of tillage options on soil physical properties and cassava-dry-matter partitioning. Field Crop. Res. 2017, 204, 191-198. [CrossRef]

27. Bhim, G.; Teodor, R.; Taru, S.; Heide, S.; Cristina, M.; Giovanna, V.; Lilian, O.S.; Isabelle, G.; Antonio, D.; Mark, L. Assessment of Benefits of Conservation Agriculture on Soil Functions in Arable Production Systems in Europe. Sustainability 2018, $10,794$.

28. Liu, C.; Li, L.; Xie, J.; Coulter, J.A.; Zhang, R.; Luo, Z.; Cai, L.; Wang, L.; Gopalakrishnan, S. Soil Bacterial Diversity and Potential Functions Are Regulated by Long-Term Conservation Tillage and Straw Mulching. Microorganisms 2020, 8, 836. [CrossRef]

29. Hassan, G.; Khan, N.U.; Munir, M. Efficacy of herbicides on weed density and grain yield of no till wheat. Int. J. Biol. Biotechnol. 2006, 3, 209-213.

30. Huang, G.-b.; Chai, Q.; Feng, F.-X.; Yu, A.-Z. Effects of Different Tillage Systems on Soil Properties, Root Growth, Grain Yield, and Water Use Efficiency of Winter Wheat (Triticum aestivum L.) in Arid Northwest China. J. Integr. Agric. 2012, 11, 1286-1296. [CrossRef]

31. Shao, Y.; Xie, Y.; Wang, C.; Yue, J.; Yao, Y.; Li, X.; Liu, W.; Zhu, Y.; Guo, T. Effects of different soil conservation tillage approaches on soil nutrients, water use and wheat-maize yield in rainfed dry-land regions of North China. Eur. J. Agron. 2016, 81, 37-45. [CrossRef]

32. Wang, L.-F.; Shangguan, Z.-P. Water-use efficiency of dryland wheat in response to mulching and tillage practices on the Loess Plateau. Sci. Rep. 2015, 5, 12225. [CrossRef] [PubMed]

33. Chan, C.; Sipes, B.; Ayman, A.; Zhang, X.; LaPorte, P.; Fernandes, F.; Pradhan, A.; Chan-Dentoni, J.; Roul, P. Efficiency of Conservation Agriculture Production Systems for Smallholders in Rain-Fed Uplands of India: A Transformative Approach to Food Security. Land 2017, 6, 58. [CrossRef]

34. Chimsah, F.A.; Cai, L.; Wu, J.; Zhang, R. Outcomes of Long-Term Conservation Tillage Research in Northern China. Sustainability 2020, 12, 1062. [CrossRef]

35. Du, B.; He, L.; Lai, R.; Luo, H.; Zhang, T.; Tang, X. Fragrant rice performances in response to continuous zero-tillage in machine-transplanted double-cropped rice system. Sci. Rep. 2020, 10, 8326. [CrossRef] [PubMed]

36. Panettieri, M.; de Sosa, L.L.; Domínguez, M.T.; Madejón, E. Long-term impacts of conservation tillage on Mediterranean agricultural soils: Shifts in microbial communities despite limited effects on chemical properties. Agric. Ecosyst. Environ. 2020, 304, 107144. [CrossRef] 
37. Pisani, O.; Liebert, D.; Bosch, D.D.; Coffin, A.W.; Endale, D.M.; Potter, T.L.; Strickland, T.C. Element losses from fields in conventional and conservation tillage in the Atlantic Coastal Plain, Georgia, United States. J. Soil Water Conserv. 2020, 75, 376-386. [CrossRef]

38. Mondal, S.; Naik, S.K.; Haris, A.A.; Mishra, J.S.; Mukherjee, J.; Rao, K.K.; Bhatt, B.P. Effect of conservation tillage and rice-based cropping systems on soil aggregation characteristics and carbon dynamics in Eastern Indo-Gangetic Plain. Paddy Water Environ. 2020, 18, 573-586. [CrossRef]

39. Man, M.; Wagner-Riddle, C.; Dunfield, K.E.; Deen, B.; Simpson, M.J. Long-term crop rotation and different tillage practices alter soil organic matter composition and degradation. Soil Tillage Res. 2021, 209, 104960. [CrossRef]

40. Sadiq, M.; Li, G.; Rahim, N.; Tahir, M. Effect of conservation tillage on yield of spring wheat (Triticum aestivum L.) and soil mineral nitrogen and carbon content. Int. Agrophys. 2021, 35, 83-95. [CrossRef]

41. Li, X.D.; Tang, Y.L.; Sui, P.; Gao, W.S.; Ma, Y.C. The Evaluation on Sustainability of Paddy Field Conservation Farming System(CFS) in Sichuan Basin, China. Acta Agron. Sin. 2007, 33, 942-948.

42. Tang, Q.; Li, S.; Xie, R.; Zhang, J.; Ren, T.; Lin, T.; Gao, S. Effects of Conservation Tillage on Crop Yield: A Case Study in the Part of Typical Ecological Zones in China. Agric. Sci. China 2011, 10, 860-866. [CrossRef]

43. Sagie, H.; Ramon, U. Using an Agroecosystem Services Approach to Assess Tillage Methods: A Case Study in the Shikma Region. Land 2015, 4, 938-956. [CrossRef]

44. Saaty, T.L. How to Make a Decision: The Analytic Hierarchy Process. Interfaces 1994, 24, 19-43. [CrossRef]

45. Saaty, T.L. The Analytic Hierarchy Process; Mcgraw-Hill: New York, NY, USA, 1980.

46. Qunshan, T. Evolution and Enlightenment of EU agricultural protection policy. Econ. Rev. J. 2010, 5, 110-113.

47. Hailin, Z.; Wangsheng, G.; Fu, C.; Wenshan, Z. Research status, development trend and countermeasures of conservation tillage. J. China Agric. Univ. 2005, 10, 16-20.

48. Fanjie, M.; Xiaofang, Y.; Julin, G.; Yiping, Z. The Bottleneck and Breakthrough path of the Conservation Tillage Development in Black Soil of Northeast China. Issues Agric. Econ. 2020, 2, 135-142. 